\title{
Application of SWAT Model for Assessing Water Availability in Surma River Basin
}

\author{
Syeda Zehan Farzana ${ }^{1,{ }^{*}}$, Md. Abu Zafor $^{1}$, Jabed Al Shahariar ${ }^{1}$ \\ ${ }^{1}$ Civil Engineering Department, Leading University, Sylhet, BANGLADESH \\ *Corresponding authors: zehan_farzana@lus.ac.bd
}

SUBMITTED 8 October 2018 REVISED 4 January 2019 ACCEPTED 14 January 2019

\begin{abstract}
Water discharge is a significant hydrological parameter because it defines the shape, size and course of the stream. This study was initiated to evaluate the performance and applicability of the physically based SWAT model in analyzing the influence of hydrologic parameters on the streamflow variability and estimation of water balance components at the outlet of Kanaighat streamflow station (SW266) of Surma basin. A 30-m resolution digital elevation model (DEM) has been used to delineate catchment boundary. Land use map obtained from global source GLOBCOVER (Europe Space Agency) has been reclassified to match the SWAT land classes. The model was first calibrated for the period from 2003 to 2008 and then validated for the period from 2009 to 2013 using the observed monthly discharge data. Statistical model performance measures, coefficient of determination $\left(\mathrm{R}^{2}\right)$ of 0.780 , the Nash-Sutcliffe Index (NSI) of 0.47 and Percent bias (PBIAS) of $-53.5 \%$, for calibration and 0.878 , 0.74 and $-31.7 \%$, respectively for validation, indicated good performance of the model simulation on monthly time step. The results showed that SWAT can simulate the hydrologic characteristics of the watershed very well.
\end{abstract}

KEYWORDS Water discharge; Surma Basin; SWAT Model; SW266; soil; land use

(c) The Author(s) 2018. This article is distributed under a Creative Commons Attribution-ShareAlike 4.0 International license.

\section{INTRODUCTION AND BACKGROUND}

Water availability is an exigent factor for deciding water resource conservation in the future as water resource management is becoming a critical issue in Bangladesh as well as for other countries all over the world. Flood forecasting, prediction of sediment loads, assessment of climate change can be possible by properly assessing the stream flows through river. (Liem \& Loi , 2012).

River plays prime source of water in Bangladesh. Clear perception of the hydrological system, the main prevailing backbone of all kinds of water movement and water pollution depends on estimation of water scarcity or water availability of river basin (Jha, 2011). Management of natural resources depends on hydrological modelling and watershed analyses. There are limited studies quantifying the current basin-wide rainfall and runoff relationship because of lack of availability or inaccessibility of rainfall data. (Nishat \& Faisal, 2000).

Recently researchers, general citizens, policy makers are so much anxious about the climate change impacts because of regular presence of flood and drought durations. (IPCC, 2013). Now a day, water quality simulation models are widely used increasingly to quantify water resource problems across the world. These models are developed in such a way that various ranges of environmental conditions, input data, model structural complexity can be operated easily. Nowadays, many hydrological models along with the application of GIS can enumerate water discharge more easily and correctly rather than traditional methods. One of them is Soil and Water Assessment Tool (SWAT) which is a basin-scale model unified with GIS technology helps to enhance the accuracy of artificial result of water discharge from rainfall and physical properties of the basin. In this integration, input data are supplied, and graphical user interface is developed by GIS and SWAT operates input data to simulate different physical processes in the basin.

The Surma is one of the major rivers in Meghna basin. The area covered by the Meghna basin is 82,000 square kilometers. Bangladesh contains $42.7 \%$ of the Meghna basin. The Surma River originated from Barak River, another river of the basin in Indian part. Barak is divided into Surma and Kushiyara while entering Bangladesh. After streaming as separate channels, 
Surma and Kushiyara are joined to form the Meghna River, which ended at Bay of Bengal (Wikipedia).

The Surma River conveys a part of the Barak river discharge and the discharges of its right bank tributaries. The inflow from Barak river to Surma is low because at the bifurcation near Amalshid, the elevation of the channel bed of the river Kushiyara is less than that of Surma. It is about $40 \%$ at high stage and zero at the lower. Since 1960's, hydro morphological features Barak river is changing and as a result major flow of Barak is discharged by Kushiyara. In this situation, Surma River could receive only $20 \%$ flow from the Barak River during monsoon season while in dry season no surge of water flows from Barak into the Surma. Because of such hydro morphological characteristics, bed level of Surma River being silted up with the resultant reduction of river depths to a large extent. Consequently, Surma River cannot accommodate hilly rain water with turbulent flow generated from upstream reach within its bed. In these circumstances, water surge overtops on both banks of the river and devastating erosion occurs in adjacent community, which also put threat to human lives and properties of Sylhet City (Rahman, 2015).

Water is considered as a precious element by human and other life being. Hydrological studies in basins are important because they help to understand processes that control water movement and the likely impacts on water quantity and quality. In this sense, the quantitative understanding of hydrological parameters (rainfall and flow) and its spatial and temporal variability in regions or river basins should be essential to an efficient planning and management of water resources (Arai, et al., 2012). To create and execute such kind of policy need the information on hydrological characteristics of the river. In this study, the discharge in Surma basin is simulated by using SWAT model to determine the present situation of the river with a different perspective based on historical data series, the data was calibrated and validated by using SWAT model for discharge of the experimental catchment, the observed and simulated discharge was compared by using the goodness of fit statistical parameters.

\section{MATERIALS AND METHODS}

The flow diagram of methodology used can be seen in Figure 1.

\subsection{Description of study area}

Sylhet, a divisional city of Bangladesh situated on the banks of Surma, a prime river in this country. It rises in north-east Indian region of Assam, flows through the city of Sylhet, and goes on to feed the river Meghna (see Figure 2). The annual average highest temperature is $23^{\circ} \mathrm{C}$ (Aug-Oct) and average lowest temperature is $7{ }^{\circ} \mathrm{C}$ (Jan). The climate is tropical monsoon bordering on a humid subtropical climate at higher elevations. The dry season is short which extends from November to February and rainy season (April to October) is characterized by heavy rains and thunderstorms almost daily and humidity is high. Nearly $80 \%$ of the annual average rainfall of $3,334 \mathrm{~mm}$ occurs between May and September.

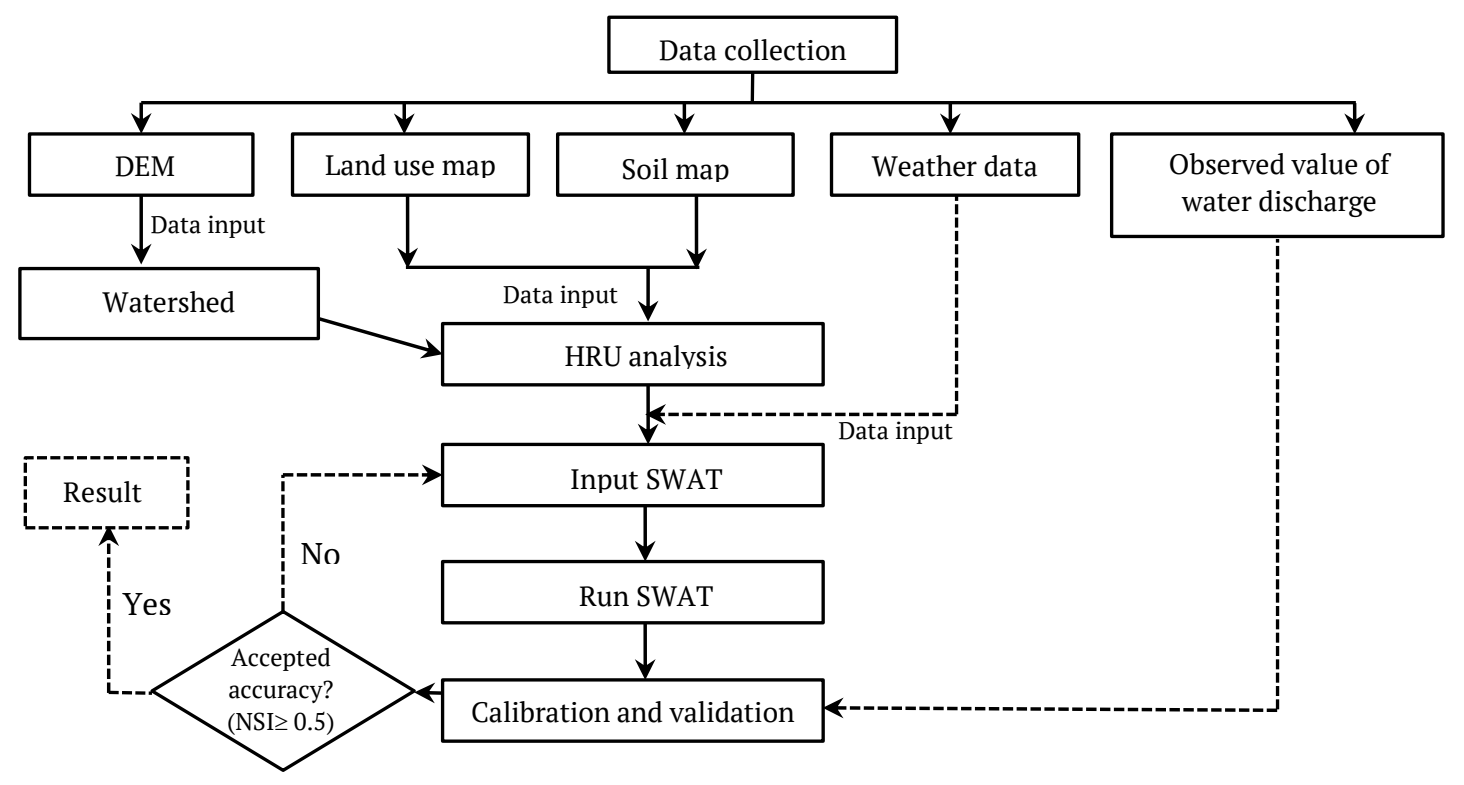

Figure 1. Flow diagram of methodology 


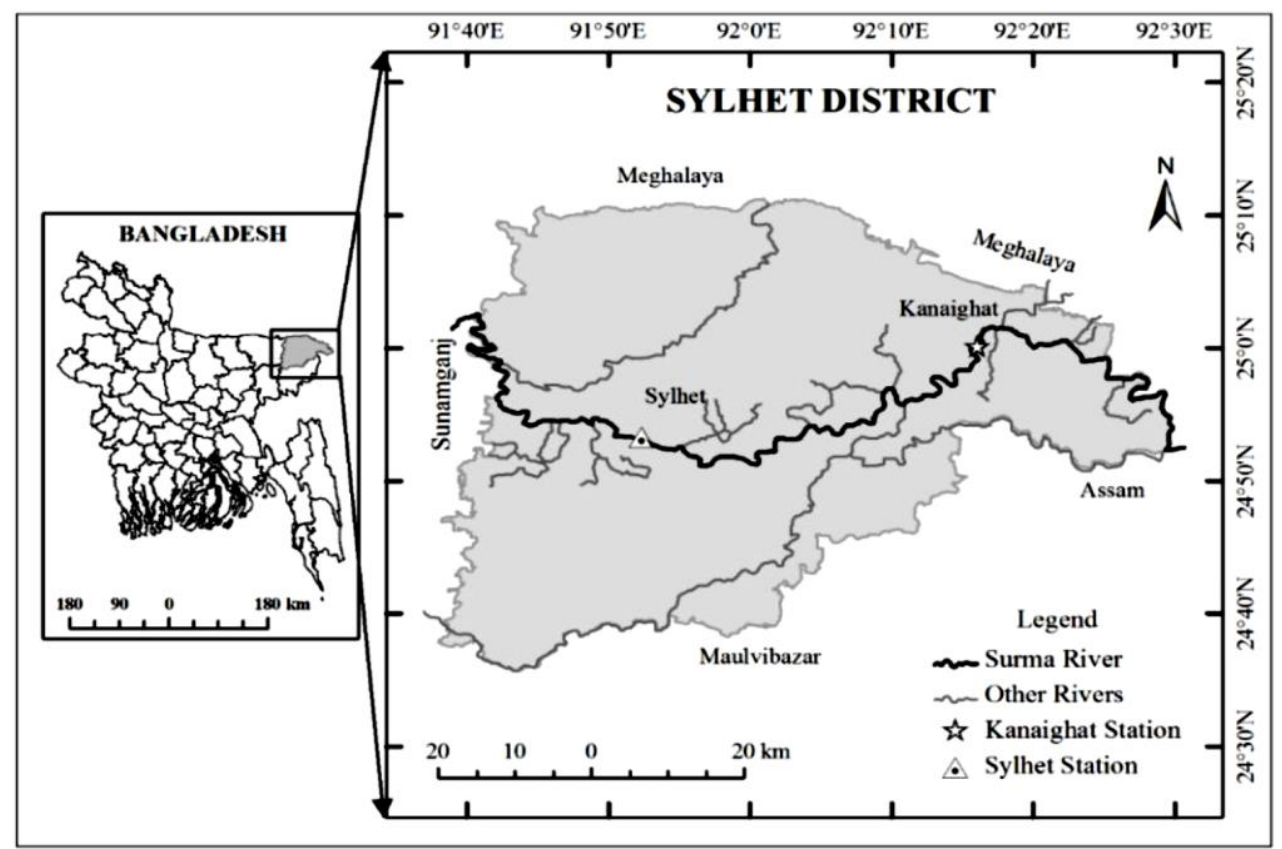

Figure 2. Map of study area

\subsection{SWAT model}

SWAT stands for Soil and Water Assessment Tool and is a river basin, or watershed, scale model. It was developed by Dr. Jeff Arnold for the USDA Agricultural Research Service (ARS). SWAT was developed to forecast the impact of land management practices on water, sediment and agricultural chemical yields in large complex watersheds with varying soils. In SWAT, a watershed is separated into multiplex subwatersheds, which are then further subdivided into hydrologic response units that consist of homogeneous land use, management, topographical, and soil characteristics. The hydrologic response units are represented as a percentage of the sub-watershed area and may not be contiguous or spatially identified within a SWAT simulation. Alternatively, a watershed can be subdivided into only sub-watersheds that are characterized by prevalent land use, soil type, and management. When irrelevant properties of soils and land uses affect hydrology of different areas of a watershed, the use of sub basins in a simulation is particularly beneficial (Tram, et al., 2014). Water balance affect plant growth and the movement of sediments, nutrients, pesticides, and pathogens and thus considered as the propulsive force of all processes in SWAT (Arnold, et al., 2012). Major hydrologic processes that can be simulated by this model include evapotranspiration, surface runoff, infiltration, percolation, shallow aquifer and deep aquifer flow, and channel routing (Arnold, et al., 1998).
The hydrologic cycle is climate guided and provides moisture and energy inputs, such as daily precipitation, $\max / \mathrm{min}$ air temperature, solar radiation, wind speed, and relative humidity, that control the water balance. The observed data can be read directly from files or generated simulated data at runtime from observed monthly statistics by SWAT. Hydrologic processes like canopy storage, surface runoff, infiltration, evapotranspiration, lateral flow, tile drainage, redistribution of water within the soil profile, consumptive use through pumping (if any), return flow, and recharge by seepage from surface water bodies, ponds, and tributary channels can be simulated by SWAT (Abbaspour, et al., 2015). SWAT uses a single plant growth model to simulate all types of land cover and differentiates among annual and perennial plants. The plant growth model is used to assess removal of water and nutrients from the root zone, transpiration, and biomass/yield production (Neitsch, et al., 2011).

\subsection{Sub-basin components}

\subsubsection{Soil Hydrology}

The hydrologic cycle as simulated by SWAT model is based on the water balance equation.

$$
S W_{t}=S W_{o}+\sum_{i=1}^{n}\left(R_{\text {day }}-Q_{\text {surf }}-E T-w_{\text {seep }}-Q_{g w}\right)
$$

Where, $S W_{t}$ is the final soil water content, $S W_{o}$ is the initial soil water content on day $i, R_{d a y}$ is the amount of precipitation on day $i, Q_{\text {surf }}$ is the amount of surface runoff on day $i, E T$ is 
the amount of evapotranspiration on day $i, w_{\text {seep }}$ is the amount of water entering the vadose zone from soil profile on day $i$, and $Q_{g w}$ is the amount of return flow on day $i$.

\subsubsection{Surface Runoff}

Surface runoff was calculated with the runoff curve number method initially developed by the Natural Resource Conservation Service (2001).

When $P<I_{a}$, then

$Q_{\text {surf }}=0$

When $P>I_{a}$, then

Qsurf $=\frac{\left(P-I_{a}\right)^{2}}{P-I_{a}-S}$

$I_{a}$ was the initial amount of water that includes surface storage, canopy interception, and infiltration before runoff $\left(\mathrm{mm} \mathrm{H}_{2} \mathrm{O}\right) . S$ was the maximum soil moisture retention after runoff begins $\left(\mathrm{mm} \mathrm{H}_{2} \mathrm{O}\right) . I_{a}$ and $S$ were determined with the runoff curve number $C N$ :

$$
S=\frac{1000}{C N}-10
$$

$I_{a}=0.2 \times S$

$C N$ had a range between 30 and 100 where values increase with runoff potential. $C N$ was determined empirically and based on soil groupings, surface characteristics such as vegetation cover or impervious surface area, and antecedent soil moisture conditions.

\subsubsection{Evapotranspiration}

The Penman-Monteith equation determined evapotranspiration or ET $\left(\mathrm{mm} \mathrm{H}_{2} \mathrm{O}\right)$ (Monteith, 1965):

$$
E T=\frac{\Delta\left(R_{n}-G\right)+\rho_{a} c_{p} g_{a} \delta_{e}}{\Delta L_{v}+L_{v} \gamma\left(1+\frac{g_{a}}{g_{s}}\right)}
$$

$R_{n}$ was the net irradiance $\left(\mathrm{Wm}^{-2}\right), G$ the ground heat flux $\left(\mathrm{Wm}^{-2}\right), \rho_{a}$ is the dry air density $\left(\mathrm{kgm}^{-3}\right), c_{p}$ is the specific heat capacity of air $\left(\mathrm{Jkg}^{-1} \mathrm{~K}^{-1}\right), g_{a}$ the conductivity of air $\left(\mathrm{ms}^{-1}\right), \mathrm{g}_{\mathrm{s}}$ the conductivity of plant stoma $\left(\mathrm{ms}^{-1}\right), \delta_{e}$ the specific humidity $(\mathrm{Pa}), L_{v}$ the volumetric latent heat of vaporization $\left(2453 \mathrm{MJm}^{-3}\right.$ for water), $\gamma$ is the psychometric constants $\left(\sim 66 \mathrm{PaK}^{-1}\right)$ and $\Delta$ is the rate of change of saturation specific humidity with air temperature $\left(\mathrm{PaK}^{-1}\right)$. Evaporative demand considered the soil layer's depth below the surface $z_{s}$ :

$$
E T_{j}=E T x \frac{z_{s, j}}{z_{s, j}+e^{2.374-0.00713 z_{s, j}}}
$$

Because the evaporative demand was different at the lower and upper boundary of the soil layer, the actual evapotranspiration was calculated as:

$$
E T_{a c t, j}=E T_{j, 1}-E T_{j, u} \text { esco }
$$

$E T_{j, 1}$ and $E T_{j, u}$ were evaporative demand at the lower and upper boundary of the soil layer and esco was the unit less soil evaporation compensation coefficient that varies between 0 and 1 .

\subsection{Input Data Sets for the study}

SWAT requires data inputs on topography, climate, land management, and soil. In this study, relevant input parameter values for the model were compiled using several different databases. These databases included both GIS data and information extracted from both soils and land use maps.

\subsection{Model Set-up}

For accurate planning and efficient utilization of the land and water resources, it is essential to understand the hydrological cycle and estimate the hydrological parameters. Calibrate and validate the model can help to evaluate the ability of the model to sufficiently predict stream-flow. For this purpose, SWAT model has been set up over the Surma basin using digital elevation model, land use data and soil data. The flow direction was determined from the processed digital elevation model and then from this model, flow accumulation is generated by addressing each cell. This accumulation counts how many upstream cells contribute to flow through given cell. The flow network can be divided into segment that will determine the outlets of the basin.

\subsubsection{Digital Elevation Data}

Digital elevation data were used in the process of SWAT-based hydrological simulation. The DEM data had a raster grid format that was equivalent to images whose pixels have spatial coordinates and units; attribute tables for the pixels and metadata accompanied the raster datasets. The DEM was required for delineating the watershed, creating the reach network, and computing the sub basin's surface characteristics. The calculated average slope grid was a necessary component in the HRU definition process. The slopes were binned into classes as HRU definition requires categorical variables. List of data source shown in Table 1. 
Table 1. Data Sources for Simulation of SWAT Model

\begin{tabular}{|c|c|c|c|}
\hline Data & Location & $\begin{array}{l}\text { Period of } \\
\text { Records }\end{array}$ & Supplying Agency \\
\hline Digital Elevation Model & Sylhet District & Unknown & $\begin{array}{l}\text { United States Geological Survey } \\
\text { (USGS) }\end{array}$ \\
\hline Land Use Map & Sylhet District & Unknown & $\begin{array}{l}\text { GLOBCOVER } \\
\text { (Europe Space Agency) }\end{array}$ \\
\hline Soil Map & Sylhet District & 1977 & $\begin{array}{l}\text { Food and Agriculture Organization } \\
\text { (FAO) }\end{array}$ \\
\hline $\begin{array}{l}\text { Weather Data (precipitation, } \\
\text { minimum/maximum temperatures, } \\
\text { relative humidity, wind speed, and solar } \\
\text { radiation) }\end{array}$ & 24 Stations & $1979-2014$ & $\begin{array}{l}\text { GWD } \\
\text { (Global Weather Data) }\end{array}$ \\
\hline Discharge Data & SW266 Station & $2003-2013$ & $\begin{array}{l}\text { Bangladesh Water Development } \\
\text { Board (BWDB) }\end{array}$ \\
\hline
\end{tabular}

\subsubsection{Watershed Delineation}

In model construction, the watershed is delineated first, and the basin is divided into sub watersheds by using topography, contour and slope from DEM. Subbasin boundaries are created using the Arc Map watershed delineation toolkit and can be manipulated based on observed routing patterns, soil types and land use.

\subsubsection{Land Use Map}

Land use data is used as the form of separate GIS-layer (either vector or raster) reclassified using crops and land use types that are defined within the model databases. This procedure requires freely available land use raster data, river networks, road networks, etc. and pre-defined sub-basins for the watershed to be processed. The land use data is shown in Table 2.

Table 2. Land use classification with total area distribution

\begin{tabular}{|c|c|c|c|}
\hline $\begin{array}{l}\text { Sr. } \\
\text { No. }\end{array}$ & $\begin{array}{l}\text { Land Use } \\
\text { Category }\end{array}$ & Code & $\begin{array}{l}\% \text { of } \\
\text { Watershed } \\
\text { Area }\end{array}$ \\
\hline 1 & $\begin{array}{l}\text { Agricultural } \\
\text { Land }\end{array}$ & AGRL & 61.11 \\
\hline 2 & Tree & TREE & 0.13 \\
\hline 3 & Rice & RICE & 32.47 \\
\hline 4 & Commercial & UCOM & 0.43 \\
\hline 5 & $\begin{array}{l}\text { Residential } \\
\text { High Density }\end{array}$ & URHD & 2.38 \\
\hline 6 & $\begin{array}{l}\text { Residential } \\
\text { Low Density }\end{array}$ & URLD & 0.45 \\
\hline 7 & Transportation & TRANSPORTATION & 0.29 \\
\hline 8 & Water & WATER & 2.74 \\
\hline
\end{tabular}

\subsubsection{Soil Map}

Soil map is separated three main soil types due to SWAT code: Eutric Gleysols, Dystric Cambisols, Eutric Cambisols. The soil map unit key column of the attribute table contains a unique identifier indicating soil type, which the SWAT model will use to gather information about hydraulic conductivity and other soil properties influencing hydrologic processes. Textural and physicochemical properties of soil such as soil texture, hydraulic conductivity, available water content, bulk density and organic carbon content for different layers of each soil type are required for SWAT model. The STATSGO file was pre-processed using a nearest neighbor re-sampling and raster re-projection to correspond to the other input files.

A 'user soil' database table was created for the study area from the available interpretations and lookup tables which are shown in Table 3.

Table 3. Properties of soil used in SWAT setup of Surma basin

\begin{tabular}{llll}
\hline Soil Name & $\begin{array}{l}\text { Percentage } \\
\text { of Clay }\end{array}$ & $\begin{array}{l}\text { Percentage } \\
\text { of Silt }\end{array}$ & $\begin{array}{l}\text { Percentage } \\
\text { of Sand }\end{array}$ \\
\hline $\begin{array}{l}\text { Eutric } \\
\text { Gleysols }\end{array}$ & 56 & 24 & 20 \\
$\begin{array}{l}\text { Eutric } \\
\text { Cambisols }\end{array}$ & 31 & 19 & 50 \\
$\begin{array}{l}\text { Dystric } \\
\text { Cambisols }\end{array}$ & 5 & 1 & 94 \\
\hline
\end{tabular}

\subsection{HRU Analysis}

HRUs were a combination of three categorical variables soil type, slope and land use. Watershed slope is derived from the digital elevation model (DEM) using the Slope Spatial Analysis tool in Arc Map 10.3. Using the DEM file as the input raster, the tool translates the elevation into a slope projection using percent slope. This parameter will be used in SWAT to fill in the subsurface lateral water movement, flow 
accumulation and routing as well as sediment yield for each sub-basin (Arnold, et al., 1998). The results of this preprocessing step create finer scale variability in slope characteristics within our study area. Hydrologic response units were created with unique combinations of land use, soil type and slope.

\subsection{Weather Data}

SWAT required daily weather/climate data that can be read from measured data set or be generated by a weather generator model. Precipitation, minimum/maximum temperatures, relative humidity, wind speed, and solar radiation data are required for the model.

\subsection{Observed value of water discharge}

Observed value of water discharge (2003-2013) has been used for model calibrations and validations.

\subsection{Outputs}

Useful model outputs are surface flow, peak flow, lateral flow, precipitation, evapotranspiration, ground water movement, soil water content, water balance. For the scope of this project, analysis focused on the discharge hydrographs created during model runs.

\subsection{Performance Evaluation of SWAT Model}

Calibration is the estimation of model parameters that cannot be directly measured and can be a manual or automated process or can be combination of the two. Validation is aimed to see whether the model can perform well. A systematic framework for model calibration and validation is given by Refsgaard and Storm (1996). A methodology for calibrating the SWAT model is described by Santhi et al. (2001). The model was run for eleven years 2003 to 2013. Calibration for the watershed was conducted for the years 2003 to 2008. Similarly, validation for the watershed was carried out for the years 2009 to 2013.

For this study, three methods were used: coefficient of determination $\left(\mathrm{R}^{2}\right)$, Nash-Sutcliffe Index (NSI) and Percent bias (PBIAS).

\subsubsection{Coefficient of determination $\left(R^{2}\right)$}

Coefficient of determination $\left(\mathrm{R}^{2}\right)$ describes the percentage of the variance in calculated data experienced by the model.

The most widely used criteria, for testing performance of a model is coefficient of determination $\mathrm{R}^{2}$ as the following Equation 9.
$R^{2}=\left(\frac{\sum_{i=1}^{n}\left(O_{i}-\bar{O}\right)\left(P_{i}-\dot{P}\right)}{\sqrt{\sum_{i=1}^{n}\left(O_{i}-\bar{O}\right)^{2}} \sqrt{\sum_{i=1}^{n}\left(P_{i}-\dot{P}\right)^{2}}}\right)$

Where, $O_{i}$ is observed flow discharge at time $i, \bar{O}$ is average observed flow discharge, $P_{i}$ is simulated flow discharge at time $i, \dot{P}$ is average simulated flow discharge, and $n$ is number of registered flow discharge data.

The general performance rating criteria developed by Sameh et al. (2011) for calibration and validation of SWAT model are given in Table 4 .

Table 4. Performance rating for $\mathrm{R}^{2}$

\begin{tabular}{ll}
\hline Performance rating & $\mathrm{R}^{2}$ \\
\hline Very Good & $\mathrm{R}^{2}>0.70$ \\
Good & $0.60<\mathrm{R}^{2} \leqslant 0.70$ \\
Satisfactory & $0.50<\mathrm{R}^{2} \leqslant 0.60$ \\
Unsatisfactory & $\mathrm{R}^{2}<0.50$ \\
\hline
\end{tabular}

\subsubsection{Nash-Sutcliffe Index (NSI)}

NSI indicates how well the plot of observed versus simulated data fits the 1:1 line. NSI is computed as shown in Equation 10.

$$
N S I=1-\frac{\sum_{i=1}^{n}\left(O_{i}-P_{i}\right)^{2}}{\sum_{i=1}^{n}\left(O_{i}-\bar{O}\right)^{2}}
$$

Performance ratings for NSI of this model are evaluated on different levels due to classification of Saleh et al. (2000) and Bracmort et al. (2006) are given in Table 5.

Table 5. Performance rating for NSI

\begin{tabular}{ll}
\hline Performance rating & NSI \\
\hline Very Well & NSI $>0.65$ \\
Adequate & $0.54<$ NSI $<0.65$ \\
Satisfactory & NSI $>0.50$ \\
\hline
\end{tabular}

\subsubsection{Percent bias (PBIAS)}

Whether the simulated data be larger or smaller than the observed data is measured by percent bias (Gupta, et al., 1999). The values of PBIAS of 0 indicate accurate model simulation. Positive values indicate model underestimated bias, and negative values indicate model overestimated bias (Gupta, et al., 1999). PBIAS is calculated with Equation 11.

PBIAS $=\frac{\sum_{i=1}^{n}\left(O_{i}-P_{i}\right)}{\sum_{i=1}^{n} O_{i}} x 100$ 


\section{RESULTS AND DISCUSSIONS}

In the present study, conventional method along Arc SWAT tool was used. The SWAT simulations were conducted for eleven years period (2003-2013). The SWAT model calibrated validated the data on monthly basis. The quality of each parameter for which the SWAT model was run and tested according of the following two criteria: Daily/monthly simulated stream flow data and annual water balance component.

\subsection{Digital Elevation Model (DEM)}

This DEM file, the base topographic input into the Arc SWAT model, is used to compute the slope and contours of the watershed. DEM values in the study area range from 101 to 291, the lower values indicate the unsaturated zones and higher values represents potential zones of saturation (Figure 3). High values were observed in the downward cells, where the water accumulated. These were located near the stream areas.

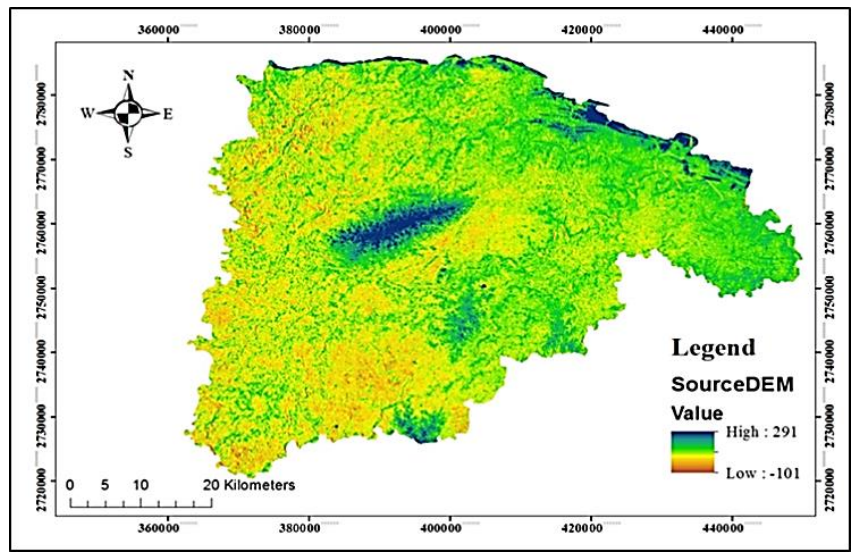

Figure 3. Digital elevation model of Surma basin

\subsection{Watershed Delineation}

After the formation of DEM, flow direction and accumulation are determined by the model using contours and watershed slope. Once flow direction and accumulation have been established, the model generates a stream network in which each individual reach drains a sub-basin, all of which drain into a major reach. Each reach has a node or outlet. The lower bound of the watershed basin is set and delineated by the location of that outlet and flow network. Areas of the watershed were $620.244 \mathrm{~km}^{2}$. Figure 4 shows the area of delineation for SW266 station of Surma basin (representative of a small area) once using DEM. This study indicates that the resolution of the DEM affects the watershed delineation as well as flow network and sub basin alignment in SWAT models.

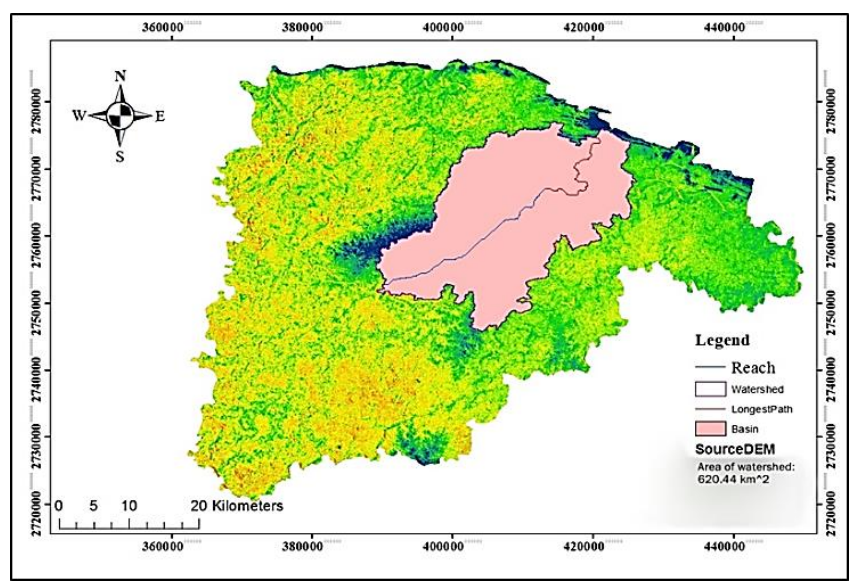

Figure 4. Watershed delineation for SW266 station of Surma basin

\subsection{Land Use Map}

The area-wise land use/land cover of the study area was computed and then plotted on a map in Figure 5 to show the land use distribution pattern all over the area. Land use map is divided into eight types based on SWAT code: rice (32.47\%), agricultural land (61.11\%), water $(2.74 \%)$, residential high density $(2.38 \%)$, residential low density $(0.45 \%)$, commercial $(0.43 \%)$, transportation $(0.29 \%)$ and tree $(0.13 \%)$.

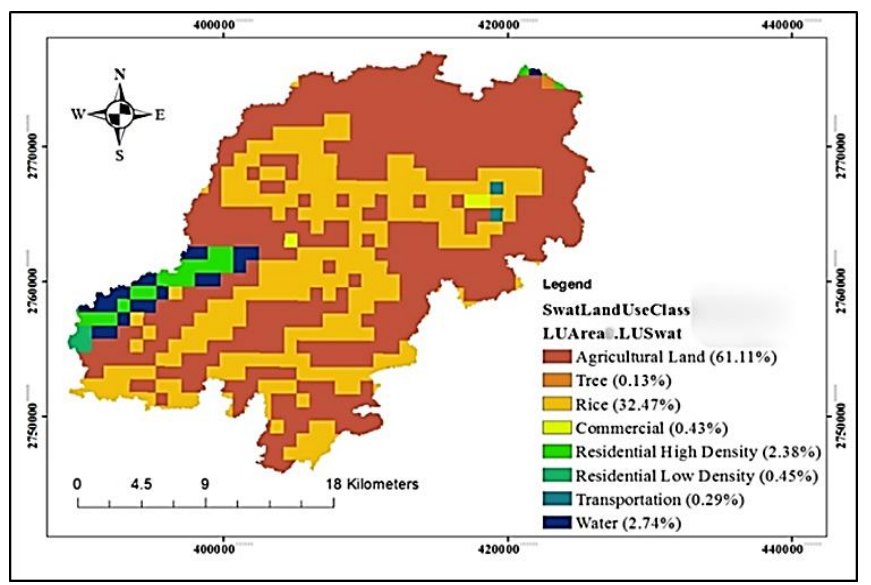

Figure 5. Land use map of Surma basin

\subsection{Soil Map}

Because of the coarse resolution, the soil class map shows only three soil type for the entire study site (Figure 6). This can clearly be refined by field samples. Three main soil types are: Eutric Gleysols (0.07\%), Dystric Cambisols (99.64\%), Eutric Cambisols (0.29\%). Eutric gleysols are clay soils that are not salty; Eutric cambisols are silt loam soils with slight profile development that is not dark in color; Dystric cambisols are sandy soils. The coverage of the soil map was prepared using the ArcGIS 10.3 software. 


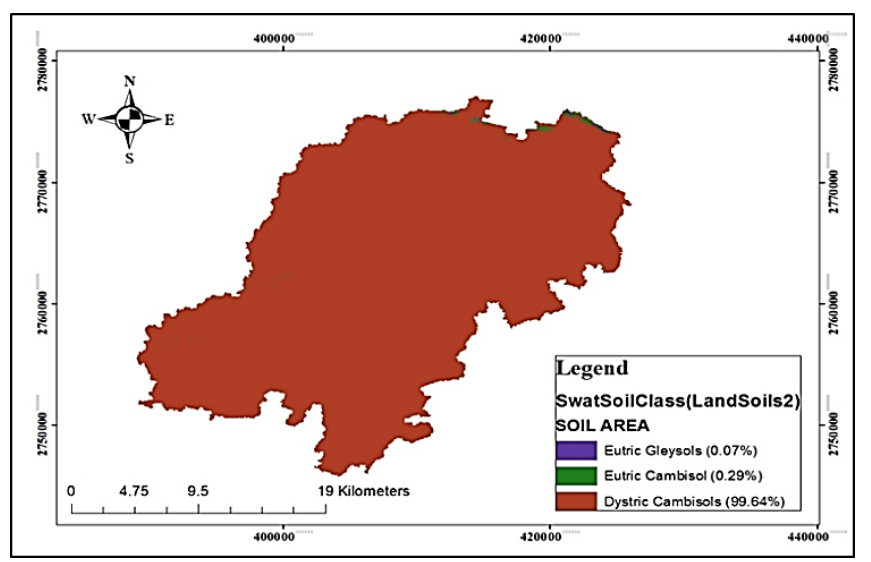

Figure 6. Soil map of Surma basin

\subsection{Model calibration}

The comparison of observed and simulated flow discharge during the calibration period (2003-2008) is shown in Figure 7. In this figure, the blue line indicates the observed flow and red line indicates the simulated flow. It is clear from the figure that the simulated stream flow reasonably matches with the observed stream flow most of the time except for the several months; the model underestimated the stream flow.

Comparison of observed and simulated flow discharge for good results with $\mathrm{R}^{2}=0.78$, NSI $=0.47$ and PBIAS $=$ $-53.5 \%$ at SW266 station of Surma basin outlet as shown in Figure 8 . The $\mathrm{R}^{2}$ value of 0.780 indicates a strong linear relationship between the observed and simulated flows. The NSI value of 0.47 indicates simulation results is adequate. The negative PBIAS value of $-53.5 \%$ indicates accurate model simulation. Accordingly, most of flow values in dry season distributed around the line $\mathrm{y}=\mathrm{x}$ whereas ones in the flood season. This result illustrated that SWAT model is capable of flow simulation in the dry season better than that in the flood season.

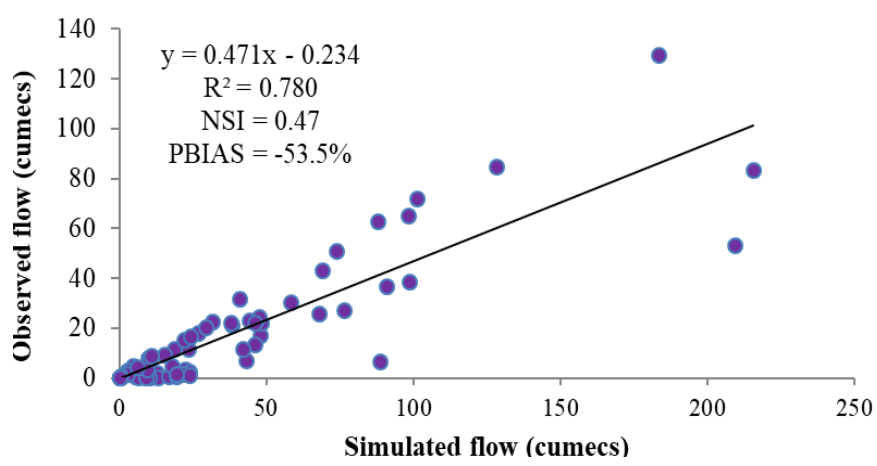

Figure 8. Relationship between observed and simulated monthly flow discharge (at SW266 station) during calibration period (2003 - 2008)

\subsection{Model validation}

The comparison of observed (blue line) and simulated flow (red line) discharge during the validation period (2009-2013) is shown in Figure 9. The simulated stream flow closely matches with the observed stream flow in most of the time periods.

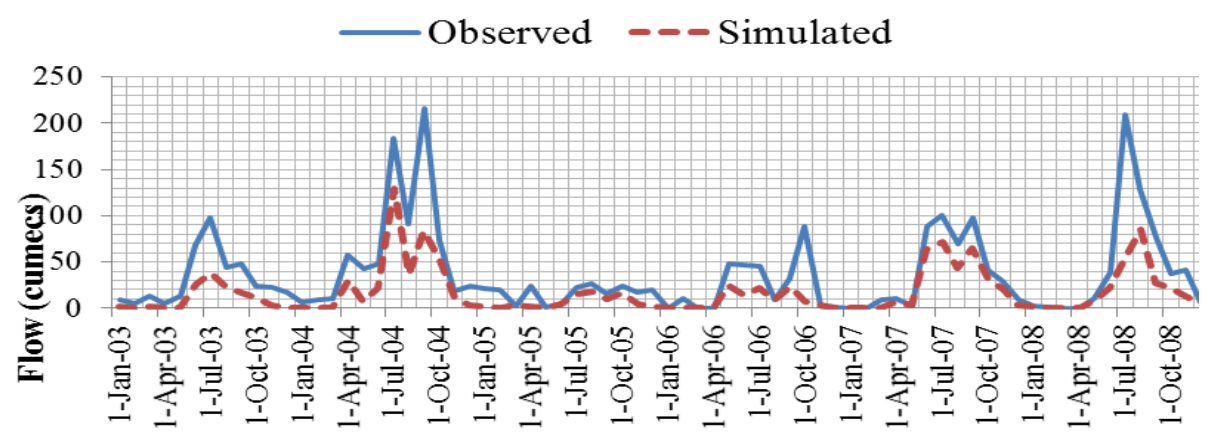

Date (Months)

Figure 7. Comparison of observed and simulated flow discharge (at SW266 station) during calibration period (2003 - 2008)

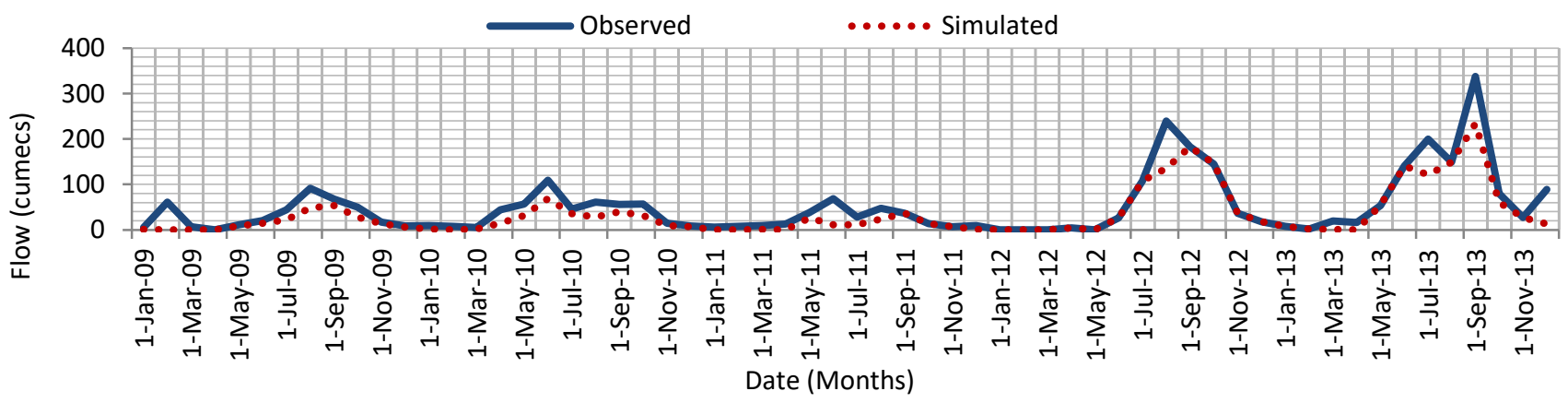

Figure 9. Comparison of observed and simulated flow discharge (at SW266 station) during validation period (2009 - 2013) 
Comparison of observed and simulated flow discharge for good results with $\mathrm{R}^{2}=0.878$, NSI $=0.74$ and PBIAS $=-31.7 \%$ at SW266 station of Surma basin outlet is shown in Figure 10. The $\mathrm{R}^{2}$ value of 0.878 indicated a strong linear relationship between the observed and simulated flows. The NSI value of 0.74 for the validation period suggested a very well relationship between the observed and simulated stream flows. The negative PBIAS value of $-31.7 \%$ indicated model overestimation bias.

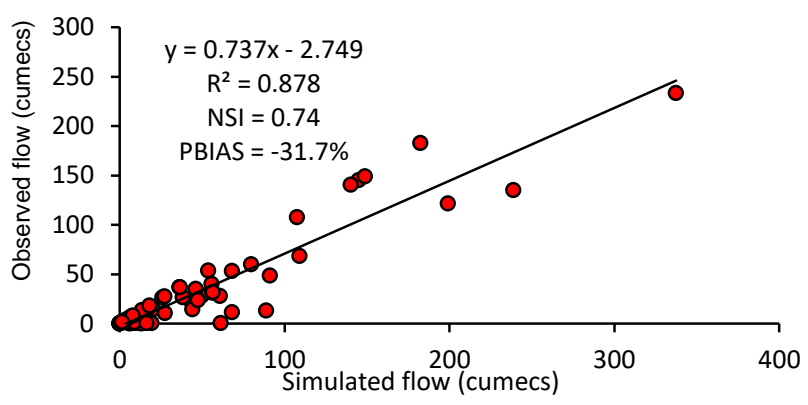

Figure 10. Relationship between observed and simulated monthly flow discharge (at SW266 station) during validation period (2009 - 2013)

The statistical results for both calibration and validation periods are summarized in Table 6 .

Table 6. Calibrated and validated data for SW266 station of Surma basin

\begin{tabular}{llllll}
\hline \multicolumn{2}{l}{ Calibration } & \multicolumn{4}{l}{ Validation } \\
\hline $\mathrm{R}^{2}$ & NSI & $\mathrm{R}^{2}$ & NSI & $\mathrm{R}^{2}$ & NSI \\
\hline 0.780 & 0.47 & 0.780 & 0.47 & 0.780 & 0.47 \\
\hline
\end{tabular}

As can be seen clearly, SWAT model simulated flow in validation shows more accuracy than in calibration. With the obtained results after calibration and validation, SWAT model applied to assess water availability in SW266 station of Surma basin, which plays an important role in social and economic development.

\subsection{Water Balance Check}

The average annual amount of main water balance elements over the area of the watershed is shown in Figure 11. Average annual values provide a starting point for a more detailed assessment of available water supply. However, the SWAT model implemented provide sufficient details to perform an analysis of surface water supply where it required. Figure 11 shows the simulated water balance elements on an annual average basis for the SW266 station of Surma basin. The results indicated that $28,105 \mathrm{~mm}$ of precipitation, $73,776 \mathrm{~mm}$ of actual evapotranspiration, $18,610 \mathrm{~mm}$ of potential evapotranspiration, 63,678 $\mathrm{mm}$ of percolation, $18,063 \mathrm{~mm}$ of soil water, 55,843 $\mathrm{mm}$ of ground water flow, $8,836 \mathrm{~mm}$ of lateral flow, $13,424 \mathrm{~mm}$ of surface flow and $20,179 \mathrm{~mm}$ of water yield. The estimated average annual water balance in the simulation period relatively matched well.

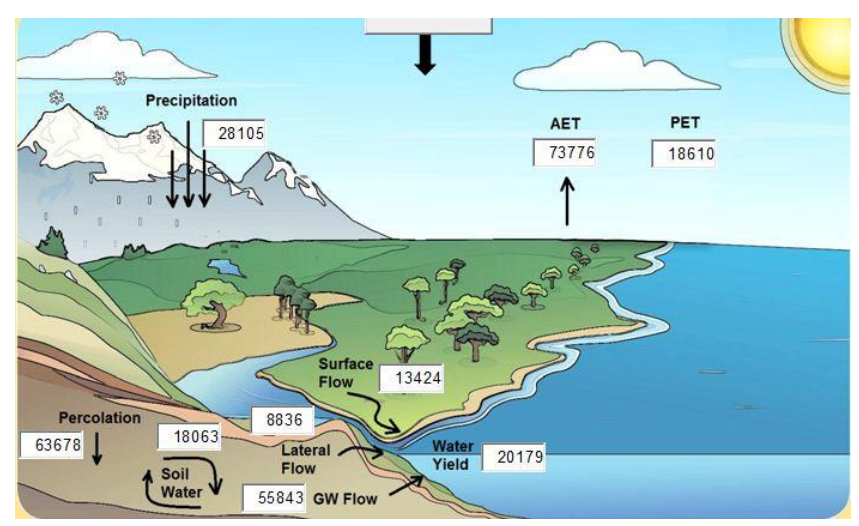

Figure 11. Model estimated annual water balance for the watershed

\section{CONCLUSIONS}

The SWAT model implemented for the watershed provides a means to assess the hydrology of the Surma basin spatially and temporally. The results proved that it is suitable to integrate GIS technology and SWAT model for simulating the water discharge in SW266 station of Surma basin and can be applied for other river basins. It is known from the hydrological water balance analysis that ground water flow is an important element of the total discharge within the study area. The limitation of this study was that only one station (SW266) of Surma basin in Sylhet area was calculated for discharge and due to the lack of daily observed data, monthly observed data were simulated.

\section{REFERENCES}

Abbaspour, K. C. et al., 2015. A continental-scale hydrology and water quality model for Europe: Calibration and uncertainty of a high-resolution largescale SWAT model. Journal of Hydrology, Volume 524, pp. 733-752.

Arai, F. K., Pereira, S. B. \& Gonçalves, G. G. G., 2012. Characterization of water availability in a hydrographic basin. Engenharia Agrícola, pp. 591-601.

Arnold, J. G. et al., 2012. SWAT: Model use, calibration, and validation. Transactions of the ASABE, pp. 14911508. 
Arnold, J. G., Srinivasan, R., Muttiah, R. S. \& Williams, J. R., 1998. Large area hydrologic modeling and assessment part I: Model development. Journal of The American Water Resources Association, 32(1), pp. 17521688.

Bracmort, K. S. et al., 2006. Modelling long-term water quality impact of structural BMPs. Transactions of the ASABE, pp. 367-374.

Cibin, R., Sudheer , K. P. \& Chaubey, I., 2010. Sensitivity and identifiability of stream flow generation parameters of the SWAT model. Hydrological Processes, pp. 1133-1148.

FAO-Unesco, 1977. Soil map of the world. Food and Agriculture Organization of the United Nations. s.l.:s.n.

FAP 6 April, 1993. Surface Water Resources of Northeast Region, Bangladesh: specialist Study, Food and Agricultural Programme.

Gupta, H. V., Sorooshian, S. \& Yapo, P. O., 1999. Status of Automatic Calibration for Hydrologic Models: Comparison with Multilevel Expert Calibration. Journal of Hydrologic Engineering, pp. 135-143.

IPCC, 2013. Climate change 2013: The physical science basis. Cambridge, UK: Cambridge University Press.

Jha, M. K., 2011. Evaluating Hydrologic Response of an Agricultural Watershed for Watershed Analysis. Water, Volume 3, pp. 604-617.

Liem , N. D. \& Loi , K. N., 2012. Assessing water discharge in Be river basin, Vietnam using SWAT model. Ho Chi Minh City, Vietnam, s.n., pp. 230-235.
Monteith, J. L., 1965. Evaporation and the Environment in the State and Movement of Water in Living Organisms. Cambridge, Cambridge University Press, pp. 205-234.

National Resources Conservation Service (NRCS), 2001. National engineering handbook. Section 4: Hydrology.. United States: National Resources Conservation Service (NRCS).

Neitsch, S. L., Arnold, J. G., Kiniry, J. R. \& Williams, J. R., 2011. Soil and Water Assessment Tool Theoretical Documentation Version 2009. Journal of Agricultural Sciences, Volume 4, pp. 11-24.

Nishat, A. \& Faisal, I. M., 2000. An assessment of the Institutional Mechanism for Water Negotiations in the Ganges-Brahmaputra-Meghna system. International Negotiations, p. 289-310.

Rahman, S. T., 2015. Morphological Study of Surma River: A Geographic Investigation, s.l.: s.n.

Refsgaard, J. C. \& Storm, B., 1996. Construction, calibration, and validation of hydrological models. Distributed Hydrologic Modeling, pp. 41-54.

Saleh, A. et al., 2000. Application of SWAT for the upper North Bosque River watershed. Transactions of the ASAE, 43(5), pp. 1077-1087.

Santhi, C. et al., 2001. Validation of the SWAT model on a large river basin with point and nonpoint sources. Journal of American Water Resources Association, 37(5), pp. 1169-1188.

Tram, V. N. Q., Liem, N. D. \& Loi, N. K., 2014. Assessing Water Availability in PoKo Catchment using SWAT model. Khon Kaen Agr. J. 42 Suppl. 2 , pp. 73-84. 